2003

\title{
Enron, Sarbanes-Oxley and Accounting: Rules Versus Principles Versus Rents
}

William W. Bratton

Follow this and additional works at: https://digitalcommons.law.villanova.edu/vlr

Part of the Accounting Law Commons, and the Securities Law Commons

\section{Recommended Citation}

William W. Bratton, Enron, Sarbanes-Oxley and Accounting: Rules Versus Principles Versus Rents, 48 Vill. L. Rev. 1023 (2003).

Available at: https://digitalcommons.law.villanova.edu/vlr/vol48/iss4/2

This Symposia is brought to you for free and open access by Villanova University Charles Widger School of Law Digital Repository. It has been accepted for inclusion in Villanova Law Review by an authorized editor of Villanova University Charles Widger School of Law Digital Repository. 


\title{
ENRON, SARBANES-OXLEY AND ACCOUNTING: RULES VERSUS PRINCIPLES VERSUS RENTS
}

\author{
William W. Bratton*
}

$\mathrm{T}$ HE stock market awakened in 2002 to discover that it no longer had numbers it could trust. ${ }^{1}$ Securities issuers, oriented toward shareholder value enhancement by the corporate culture of the 1990s, had been adopting aggressive, even fraudulent treatments to enhance reported earnings, and their auditors had been doing nothing to stop them. So long as the money kept falling out of the sky during the bull market, nobody worried about the diminishing independence of auditors. But what was ignored before 2001 triggered a crisis in 2002 in markets already reeling on economic fundamentals. As the audit failures piled up on one another, investors lost confidence in managers, market intermediaries and auditors alike. ${ }^{2}$

\footnotetext{
* Samuel Tyler Research Professor of Law, The George Washington University Law School.

1. See, e.g., Gretchen Morgenson, Worries of More Enrons to Come Give Stock Prices a Pounding, N.Y. Timfs, Jan. 30, 2002, at Cl. For a review of the Enron disaster, see William W. Bratton, Enron and the Dark Side of Shareholder Value, 76 TuL. L. REV. 1275 (2002).

2. A General Accounting Office report notes that public company restatements rose from 92 in 1997 to 225 in 2001. From 1997 to June 2002, there were 919 announced restatements, involving 845 companies, which came to ten percent of all those listed. See Financial Restatements: Trends, Market Impacts, Regulatory Responses, and Remaining. Challenges, General Accounting Office Report to the Chairman, Senate Comm. on Banking, Housing, and Urban Affairs (Oct. 2002) (GAO-03-138), available al http://www.gao.gov [hereinafter GAO REPORT].

The decline in compliance has not been limited to companies subject to enforcement actions, like Cendant and Sunbeam. See In re Cendant Corp. Sec. Litig., 109 F. Supp. 2d 235, 239 (D.N.J. 2000); Chad Terhune \& Joanne S. Lublin, Unlike Others, Dollar General Issues a Mea Culpa, WALL ST. J., Jan. 17, 2002, at B1 (noting Dollar General's public apology and admission of guilt for its accounting irregularities in same week that "Chainsaw" Al Dunlop paid \$15 million settlement stemming from Sunbeam's fraudulent financials). Investigations and criticisms touch reputable names like Xerox, Lucent, American International, Coca Cola, IBM and General Electric itself. See Claudia H. Deutsch \& Reed Abelson, Xerox Facing New Pressures Over Auditing, N.Y. Times, Feb. 9, 2001, at C1; Jeremy Kahn, Accounting in Wonderland: Jeremy Kahn Goes Down the Rabbit Hole with G.E.'s Books, Fortune, Mar. 19, 2001, at 37; Steve Liesman, Heard on the Street: Deciphering the Black Box, WALL ST. J., Jan. 23, 2002, at C1 (noting that, after Enron scandal, investors will closely scrutinize books and practices of companies like Coca-Cola, GE and AIG); Simon Romero, Lucent's Books Said to Draw Attention of the S.E.C., N.Y. Times, Feb. 10, 2001, at C1; Rachel Emma Silverman \& Ken Brown, Five Companies: How They Get Their Numbers, WALL Sr. J., Jan. 19, 2002, at C1, C16 (noting complexity of major corporations' books make it almost impossible to accurately assess financial status of company). The number of accounting restatements, when companies lower previously reported earnings, averaged forty-nine per year from
} 
In our self-regulatory system of corporate law, the job of insisting on trustworthy numbers devolves in the first instance on the gatekeepers. It follows that the auditors take the brunt of the blame and that the Sarbanes-Oxley Act (the "Act"), ${ }^{3}$ the legislation intended to address the scandals and restore confidence in the securities markets, responds by regulating the accounting profession. More accurately, Sarbanes-Oxley triggers the start of a political process intended over time to produce a new regulatory regime. The statute follows the standard regulatory strategy of delegating most of the task of devising the new regime's terms to an administrative agency, a new Public Oversight Board (POB). ${ }^{4}$ The regulatory outcome remains open accordingly. High financial stakes imply an ongoing political contest over the POB's political and institutional gestalt and the terms of any new regulation. The resulting uncertainty, although regrettable, probably could not have been avoided.

Unfortunately, Sarbanes-Oxley does not stop with an open-ended delegation of authority respecting the audit function to a new agency. The Act goes on to address the substance of Generally Accepted Accounting Principles (GAAP). It does this first in section $108(\mathrm{~d})$, which requires the SEC to study the accounting system to ascertain the extent to which it is "principles-based," as opposed to "rules-based," and to tell us how long it will take for us to achieve a "principles-based" system; ${ }^{5}$ and second, in section 108(a), which requires the Financial Accounting Standards Board

1990 to 1997 . By 2000, the annual number was up to 156 . See Liesman, supra, at C1.

3. See generally Sarbanes-Oxley Act of 2002, Pub. L. No. 107-204, 116 Stat. 745 (codified in scattered sections of Titles 11, 15, 18, 28 and 29 U.S.C.). For a discussion of the meaning of the audit crisis for the legal profession, see Lawrence A. Cunningham, Sharing Accounting's Burden: Business Lawyers in Enron's Dark Shadows, 57 Bus. Law. 1421 (2002).

4. Sarbanes-Oxley Act $\$ 103(\mathrm{a})(1)$. The Act provides:

(1) IN GENERAL.-The Board shall, by rule, establish, including, to the extent it determines appropriate, through adoption of standards proposed by 1 or more professional groups of accountants . . . or advisory groups ... ., and amend or otherwise modify or alter, such auditing and related attestation standards, such quality control standards, and such ethics standards to be used by registered public accounting firms in the preparation and issuance of audit reports, as required by this Act or the rules of the Commission, or as may be necessary or appropriate in the Id. public interest or for the protection of investors.

5. Sarbanes-Oxley Act $\$ 108$ (d) provides in pertinent part:

SEC. 108. ACCOUNTING STANDARDS.

\footnotetext{
(d) STUDY AND REPORT ON ADOPTING PRINCIPLES-BASED ACCOUNTING.-

(1) STUDY.-

(A) IN GENERAL. - The Commission shall conduct a study on the adoption by the United States financial reporting system of a principles-based accounting system.

(B) STUDY TOPICS.-The study required by subparagraph (A) shall include an examination of-
} 
(FASB) and any other approved standards-setting body to adopt procedures ensuring prompt consideration of new rules reflecting "international convergence on high quality accounting standards." 6 Given an

(i) the extent to which principles-based accounting and financial reporting exists in the United States;

(ii) the length of time required for change from a rules-based to a principles-based financial reporting system;

(iii) the feasibility of and proposed methods by which a principlesbased system may be implemented; and

(iv) a thorough economic analysis of the implementation of a principles-based system.

(2) REPORT.-Not later than 1 year after the date of enactment of this Act, the Commission shall submit a report on the results of the study required by paragraph (1) to the Committee on Banking, Housing, and Urban Affairs of the Senate and the Committee on Financial Services of Id. the House of Representatives.

6. Sarbanes-Oxley Act $\$ 108(a)(2)(b)(1)(A)(v)$. Section 108(a) provides in pertinent part:

SEC. 108. ACCOUNTING STANDARDS.

(a) AMENDMENT TO SECURITIES ACT OF 1933-Section 19 of the Securities Act of 1933 (15 U.S.C. 77s) is amended-

(2) by inserting after subsection (a) the following:

(b) RECOGNITION OF ACCOUNTING STANDARDS.-

(1) IN GENERAL.-In carrying out its authority ... the Commission may recognize, as 'generally accepted' for purposes of the securities laws, any accounting principles established by a standard setting body-

(A) that-

(i) is organized as a private entity;

(ii) has, for administrative and operational purposes, a board of trustees (or equivalent body) serving in the public interest, the majority of whom are not, concurrent with their service on such board, and have not been during the 2-year period preceding such service, associated persons of any registered public accounting firm; of 2002 ;

(iii) is funded as provided in section 109 of the Sarbanes-Oxley Act

(iv) has adopted procedures to ensure prompt consideration, by majority vote of its members, of changes to accounting principles necessary to reflect emerging accounting issues and changing business practices; and

(v) considers, in adopting accounting principles, the need to keep standards current in order to reflect changes in the business environment, the extent to which international convergence on high quality accounting standards is necessary or appropriate in the public interest and for the protection of investors; and

(B) that the Commission determines has the capacity to assist the Commission in fulfilling the requirements of subsection (a) and section 13(b) of the Securities Exchange Act of 1934 [15 U.S.C.A. 78m], because, at a minimum, the standard setting body is capable of improving the accuracy and effectiveness of financial reporting and the protection of investors under the securities laws.

(2) ANNUAL REPORT.-A standard setting body described in paragraph (1) shall submit an annual report to the Commission and the pubId. lic, containing audited financial statements of that standard setting body.". 
ongoing political contest respecting the shape of the POB and its regulatory program, critical questions need to be asked about these substantive initiatives.

More particularly, this Article asks whether substantive intervention into the articulation of GAAP could trigger just the sort of regulatory error that the agency delegation model, followed in respect of the POB, was intended to avoid. "Principles-based accounting" and "international convergence," however desirable in the abstract, have to be considered in light of the institutional contexts in which they would operate and effect consequences. "Principles" and "convergence," by themselves do little to constrain rent-seeking behavior on the part of managers and auditors. Absent antecedent institutional reform that ensures auditor independence and lessens the negative impact of rent-seeking and influence activity on audit quality, perverse effects could follow in the event that sections 108(d) and 108(a) influence GAAP's future shape. ${ }^{7}$ Unfortunately, Sarbanes-Oxley does not ensure the requisite institutional reform; it merely holds out the possibility of reform.

Part I describes Sarbanes-Oxley's delegation to the POB, surveying the issues the Act leaves open and the ongoing political contest respecting their resolution. ${ }^{8}$ Part II situates the principles-based accounting that the Act commends in the context of the Enron disaster. ${ }^{9}$ This discussion begins with a story currently in circulation-that Enron exemplifies the abuses of rules-based accounting under GAAP and demonstrates the need to move to principles-based accounting. The discussion then falsifies the story, showing that Enron violated both rules and standards under GAAP. Full responsibility for the disaster goes to the enforcement of GAAP's rules and standards by Enron's auditor rather than to the rules and standards themselves. The discussion then broadens, explaining why the relative merits of rules and principles are being debated in respect of GAAP at this time, and how the principles-based argument rests on a false premise, holding out risks for audit quality.

\section{The Delegation Gamble}

The drafters of Sarbanes-Oxley could not reasonably have been expected to produce an exhaustive new scheme of regulation for the accounting profession. With accounting, as with all professions, information asymmetries between insiders and outsiders make regulation difficult. The problems for solution-inappropriate and aggressive treatments, auditor independence and audit quality - do not lend themselves to ex ante

7. Section 108 (d) already has forced FASB to take steps toward a more principles-based regime. See Financial Accounting Standards Board, PrinciplesBased Approach to U.S. Standard Setting, No. 1125-001 (October 21, 2002) [hereinafter FASB, Principles APPROACH].

8. See infra notes $13-46$ and accompanying text.

9. See infra notes 47-110 and accompanying text. 
treatment by an exhaustive and self-executory set of legislative directions. The time-honored strategy of delegating open-ended legislative and adjudicatory authority to an agency works better; here, the new agency combines a regulator with a professional disciplinary board. The new agency can be staffed with insider experts, who can then tailor regulations to particular facts and circumstances and deal case by case with those who commit professional misconduct. Sarbanes-Oxley proceeds on these assumptions, vesting a wide range of regulatory authority in the new POB. Under section 101(c), the POB is to "establish or adopt, or both, by rule, auditing, quality-control, ethics, independence, and other standards relating to the preparation of audit reports;" 10 to "conduct inspections of registered public accounting firms;" 11 and to conduct "disciplinary proceedings" in respect of firms and their personnel. ${ }^{12}$ The new regime's substantive content, like the investigations themselves, is to be left over to the POB, subject to the ultimate supervision of the Securities and Exchange Commission (SEC). ${ }^{13}$

Sarbanes-Oxley "hard wires" some incidental regulations, directing the $\mathrm{POB}$ to promulgate specific rules respecting matters such as retention of audit records, audit partner review and auditor review of internal controls. ${ }^{14}$ But, for the most part, the Act contains very little direct regulation of accounting treatments and audit practice. Indeed, the more controversial the subject matter, the more hesitant the drafters of Sarbanes-Oxley became. On a number of key topics, the Act avoids prohibiting, directing or even delegating, preferring to order up studies from third party agencies. ${ }^{15}$ The drafters in effect look to the standard playbook of an outside director facing an adverse development, but articulating no coherent response and possessing no pertinent expertise. For example, the Act orders a Comptroller General study of audit firm rotation, ${ }^{16}$ where the Act actually mandates the lesser palliative of audit partner rotation. ${ }^{17}$ The Comptroller General also is directed to study auditor consolidation and concentration, and to look into concentration's effect on audits and independence in so doing. ${ }^{18}$

10. Sarbanes-Oxley Act $\S 101$ (c) (2).

11. Id. $\$ 101(\mathrm{c})(3)$.

12. Id. $\S 101(\mathrm{c})(4)$.

13. The regulatory model tracks that of the securities trading organizations, like the New York Stock Exchange and the National Association of Securities Dealers. See id. $\S 107$ (a).

14. See id. $\$ 103(\mathrm{a})(2)$.

15. The drafters in effect looked to the outside director's standard expedient of employing an expert and ordering a study given an adverse development, no pertinent expertise and no coherent response.

16. Sarbanes-Oxley Act $\$ 207$.

17. Id. $\S 203$.

18. See id. $\$ 701$. The provision provides as follows:

SEC. 701. GAO STUDY AND REPORT REGARDING CONSOLIDATION OF PUBLIC ACCOUNTING FIRMS. 
Surprisingly, audit practice itself is not included on Sarbanes-Oxley's list of studies. If the Act's drafters had been serious about gauging the scope of the problem and getting to the roots of the crisis, one would have expected them to direct a study of prevailing audit practice and its connection to recent audit failures. Audit firm concentration, although also an important topic, only approaches by indirection the critical questions concerning audit quality and auditor incentives. Before considering the counterfactual question of how a world with, say, fifteen large audit firms would differ from the world of the Final Four firms, one needs to know just how low the standard of audit practice has sunk. Whatever the ideal number of large firms, we need findings respecting the degree of noncompliance with GAAP customarily tolerated by audit partners and the practices and concepts on which the accounting profession draws on in its internal discussions when it sanctions departures from GAAP.

(a) STUDY REQUIRED.-The Comptroller General of the United States shall conduct a study-

(1) to identify-

(A) the factors that have led to the consolidation of public accounting firms since 1989 and the consequent reduction in the number of firms capable of providing audit services to large national and multi-national business organizations that are subject to the securities laws;

(B) the present and future impact of the condition described in subparagraph $(A)$ on capital formation and securities markets, both domestic and international; and

(C) solutions to any problems identified under subparagraph (B), including ways to increase competition and the number of firms capable of providing audit services to large national and multinational business organizations that are subject to the securities laws;

(2) of the problems, if any, faced by business organizations that have resulted from limited competition among public accounting firms, including-

(A) higher costs;

(B) lower quality of services;

(C) impairment of auditor independence; or

(D) lack of choice; and

(3) whether and to what extent Federal or State regulations impede competition among public accounting firms.

(b) CONSULTATION.-In planning and conducting the study under this section, the Comptroller General shall consult with-

(1) the Commission;

(2) the regulatory agencies that perform functions similar to the Commission within the other member countries of the Group of Seven Industrialized Nations;

(3) the Department of Justice; and

(4) any other public or private sector organization that the Comptroller General considers appropriate.

(c) REPORT REQUIRED.- Not later than 1 year after the date of enactment of this Act, the Comptroller General shall submit a report on the results of the study required by this section to the Committee on Banking, Housing, and Urban Affairs of the Senate and the Committee Id. on Financial Services of the House of Representatives. 
One could draw a negative inference at this point and infer that the omission reflects the drafters' preference for actions that create an appearance of corrective activity without actually promising to achieve correction. A possible correction that might follow, for example, if the Act were to cause the harsh light of publicity to be cast on day-to-day audit practice at the Final Four audit firms. A glimpse of a sordid reality, thus engineered, might trigger pressure for a more intense reform program-a program outside the box of reform contemplated by the political settlement from which Sarbanes-Oxley's drafters took their directions. Whatever the results of the study of industry concentration, it seems unlikely that Congress will respond by busting up the Final Four firms.

The agency delegation model suggests a less malignant explanation, however. The Act mandates no direct investigation of audit practice because the subject matter lies in the POB's future zone of responsibility. If the $\mathrm{POB}$ needs to do extensive fact finding as it goes about articulating quality control standards ${ }^{19}$ and conducting inspections ${ }^{20}$ of audit firms, it has the authority to do so.

The problem lies not in the agency authorization but in the future execution. As the Act delegates more and more to a new agency, the regulatory outcome is placed more and more at risk. To see the high degree of reliance the Act places on the agency it creates, consider its provision on consulting arrangements between auditors and their clients. ${ }^{21}$ This intervention bears directly on the crisis of confidence. Historically, the accounting firms' interest in maintaining reputations for proper performance, coupled with a backstop threat of legal liability, imported a needed adverseness to the auditor-client relationship. ${ }^{22}$ In the 1990s, however, two factors changed. First, the liability system was adjusted to make accounting firms less susceptible to liability to private plaintiffs. ${ }^{23}$ Second, by 2000 the Big Five firms' revenues for non-audit or "management advisory" services grew to fifty percent of total revenues, where twenty years earlier they had constituted only thirteen percent of total rev-

19. See id. $\$ 103(\mathrm{a})(1)$.

20. See id. $\S 104(\mathrm{a})$.

21. See id. § 103(a) (2) (B) (ii).

22. Or at least a degree of adverseness more intense than that prevailing in the 1990s. For the view that the incentive-incompatible fact that the client's managers pay the fee assures the persistence of independence problems, see Sean M. O'Connor, The Inevitability of Enron and the Impossibility of "Auditor Independence" Under the Current Audit System, (SSRN working paper, 2002), available at http:// www.ssrn.com.

23. The Private Securities Litigation Reform Act of 1995 erects a substantial pleading barrier to private accountant's liability. See Section 21(D)(b)(2) of the Securities Exchange Act of 1934. In addition, a line of cases holds that, absent a direct financial interest in the client, an auditor's interest in a reputation for honesty and care makes an allegation of scienter implausible. See Melder v. Morris, 27 F.3d 1097, 1103 (5th Cir. 1994); DiLeo v. Ernst \& Young, 901 F.2d 624, 629 (7th Cir. 1990); Retsky Family Ltd. P'ship v. Price Waterhouse LL.P, 1998 U.S. Dist. LEXIS 17459, *23-29 (N.D. Ill. Oct. 21, 1998). 
enues. ${ }^{24}$ The audit firms' incentive to take positions adverse to their clients' with respect to aggressive treatments diminished correspondingly. Consider, by way of illustration of the problem, that one of the most important reviews in the audit concerns the client's internal control and monitoring systems. An auditor is hardly likely to question the effectiveness of a compliance system sold by his or her own firm. Yet through the 1990 s, auditing firms were also routinely selling compliance systems to their clients-Andersen sold Enron its compliance system in 1993. ${ }^{25}$

The Enron disaster, with its combination of sham transactions and antecedent (and lucrative) auditor consultation in the sham transactions' structure, demonstrated that consulting relationships can indeed contribute to catastrophic audit failures. ${ }^{26}$ The governance breakdown in the case was multifaceted. It only began with internal compliance systems and board monitoring at Enron and monitoring by outside actors in the marketplace. Just as accounting clients have these internal governance systems to assure that disasters do not happen, so do audit firms. Auditing is such a high-risk business that audit firms have elaborate internal control and monitoring systems, reviewing their own performance to a degree unknown in law firms. ${ }^{27}$ Yet the Enron disaster occurred despite this second level compliance system-Andersen's head office passed on the shams because it projected growing revenues from Enron consulting. ${ }^{28}$ The multiple compliance systems collapsed under the all powerful, downward gravitational pull of rents.

Prior to Sarbanes-Oxley and the Enron crack up, pursuant to a rule promulgated in 2000, the SEC prohibited auditors from providing a list of services, including bookkeeping, financial information systems design, appraisal or valuation services, actuarial services, fairness opinions, management functions and financial implementation systems design and implementation. ${ }^{29}$ The Act's section 201 follows up after the fact with the following provision:

[I]t shall be unlawful for a ... public accounting firm . . that performs for any issuer any audit . . . to provide to that issuer, contemporaneously with the audit, any non-audit service, including-

24. See John C. Coffee, Jr., The Acquiescent Gatekeeper: Reputational Intermediaries, Auditor Independence, and the Governance of Accounting, Columbia Law School Center for Law and Economic Studies Working Paper No. 191 (2001), at 27.

25. See Thaddeus Herrick \& Alexei Barrionuevo, Were Auditor and Client Too Close-Knit?, WaLl St. J., Jan. 21, 2002, at C1.

26. See Bratton, supra note 1, at 1348-51.

27. See John C. Coffee, Jr., Understanding Enron: "It's About the Gatekeepers, Stupid", 57 Bus. Law. 1403, 1415 (2002).

28. See Internal Arthur Andersen Memorandum, from Michael D. Jones to David B. Duncan (Feb. 6, 2001) (on file with author).

29. See Revision of the Commission's Auditor Independence Requirements, 65 Fed. Reg. 76,008-01 (2000) (codified at 17 C.F.R. $\$ \$ 210.2-01,240.14 \mathrm{e}-101$ ). 
(1) bookkeeping or other services related to the accounting records or financial statements of the audit client;

(2) financial information systems design and implementation;

(3) appraisal or valuation services, fairness opinions, or contribution-in-kind reports;

(4) actuarial services;

(5) internal audit outsourcing services;

(6) management functions or human resources;

(7) broker or dealer, investment adviser, or investment banking services;

(8) legal services and expert services unrelated to the audit; and

(9) any other service that the Board determines, by regulation, is impermissible. ${ }^{30}$

The provision has been said to impose an absolute bar on consulting. ${ }^{31}$ Yet the reader comparing it to the list in the SEC regulation sees at once that the Act only carries over the antecedent, partial list. ${ }^{32}$ The Act does imply an advance on the previous regulation in the form of an absolute bar when it introduces the list with the phrase, "any non-audit service including." This suggests that the list is for illustration only and that the controlling concept is "any non-audit service," which would be prohibited whatever its nature. But that reading is undercut when the list ends with the item, "any other service that the Board determines, by regulation, is impermissible." This implies that services not on the list are permitted until such time as the $\mathrm{POB}$ gets around to extending the prohibition.

On its face, then, section 201 raises an issue of statutory interpretation: Whether it flatly bars non-audit services or merely offers a now-yousee-it-now-you-don't perpetuation of the regulatory status quo. The latter reading makes perfect sense in the overall context of the legislation, even as it appears to undercut its reformatory mission. Under the latter reading, the Act effects no substantial present changes, instead delegating to the $\mathrm{POB}$ authority to effect change in the future. The reading brings sec-

30. Sarbanes-Oxley Act $\S 201$ (a) (2002) (amending Section 10A of the Securities Exchange Act of 1934,15 U.S.C. $\$ 78 \mathrm{j}-1)$. The section goes on to require preapproval by the audit committee for non-audit services. See id. $\$ 201(\mathrm{~h})$.

31. See Strengthening the Commission's Requirements Regarding Auditor Independence, Final Rule, Securities Act Release No. 33-8183, Exchange Act Release No. 34-47265, 65 Fed. Reg. 6005 (Feb. 5, 2003), available at http://www.sec.gov/ rules/proposed/33-8183.htm (finding that subsection $(\mathrm{g})$ of section 201 specifies several non-audit services that are prohibited).

32. See id. (noting that only perceived difference is that statute makes absolute bar to information systems design that previously was partial). 
tion 201 into line with the Act's other key provisions respecting the accounting profession. ${ }^{33}$

This story of benign delegation has a dark side, however. Under the delegation reading, the flow of rents to the Final Four firms continues unabated for the present. The matter of future rent constraints is left to be determined in the context of the emerging relationship between the $P O B$ and the industry. Should the Final Four firms gain any influence over the $\mathrm{POB}$, one can expect their number one agenda item to be the protection of their rents from further restriction. A lot of money is at stake, even as the accounting firms loudly divest themselves of consulting divisions. ${ }^{34}$ As of the third quarter of 2002, fifty percent of the Final Four's revenues still were coming from non-audit services. ${ }^{35}$ Meanwhile, the only rents Sarbanes-Oxley actually cuts off are those of corporate managers, who will be required to pay back their bonus payments in the wake of any accounting restatements. ${ }^{36}$

Sarbanes-Oxley's reliance on the delegation model thus raises a political question. The agency delegation model works well only so long as the agency successfully resists capture by the interests of the actors it regulates. In the standard picture, capture problems arise over time, as the agency and the regulated entities deal with one another on a repeated basis. Early in the agency's life cycle, immediately following enactment of the generating statute, its actors maintain an adverse posture, perhaps activated by an original regulatory vision. Later on, personal career interests, interest group influence activities and the cooperative dispositions that accompany personal relationships can cause administrators' motivations to shift in a more accommodating direction. ${ }^{37}$ The regulatory mission becomes compromised as a result.

To read the cold print of Sarbanes-Oxley is to see no apparent reason for concern about compromise of the POB's mission. The POB will operate under the supervision of the SEC, and the SEC, whatever mistakes it

33. The SEC reads the statute this way. New SEC rules, promulgated under section 201, further elaborate on the items on the list, incrementally extending the standing services prohibition, without breaking any new ground. See id.

34. See Cassell Bryan-Low, Accounting Firms Are Still Consulting, WALL. ST. J., Sept. 23, 2002, at C1, C7. Current consulting revenues represent a substantial decrease: PricewaterhouseCoopers took in $\$ 9.16$ billion total revenues pre-divestiture and $\$ 5.26$ billion post-divestiture; Ernst \& Young took in $\$ 6.10$ billion pre and $\$ 4.49$ billion post; Deloitte \& Touche took in $\$ 6.13$ billion pre and $\$ 4$ billion post; KPMG took in $\$ 5.45$ billion pre and $\$ 3.42$ billion post. See id. (representing postdivestiture earnings in graph).

35. See id. ("Accounting firms continue to advise on everything from management processes to tax-minimization strategies to corporate finance to security of clients' computer networks ....").

36. See Sarbanes-Oxley Act $\$ 304(a)$.

37. See lan ayres \& John Braithwaite, Responsive Regulation: TranSCENDING THE DeREgulation Debate 54-56 (1992) (describing circumstances of business regulation that lead to cooperation, corruption and capture). 
has made in its long history, has never had its independence seriously questioned.

The prevailing political context nevertheless holds out reasons for concern. In this case the political struggle between the public interest and the interest of the regulated industry has continued unabated in the immediate wake of the statute's enactment. The accounting profession has become famously aggressive at protecting its own interests and those of its clients in the corridors of power in Washington. During the 1990s it used its influence to stifle FASB's reform initiatives concerning accounting for stock options and accounting for mergers. ${ }^{38}$ The industry's lobbyists pulled out the stops again when Arthur Levitt's SEC suggested that fees from consulting services were compromising auditor independence. Although, as noted above, the SEC did promulgate a new set of independence rules, those rules embodied a compromise effected after a period of intense political struggle. ${ }^{39}$

Enron and other scandals put the accountants and their Washington representatives more and more on the defensive as 2002 unfolded. Sarbanes-Oxley represented a strategic defeat for their side. Even so, the accountants and their representatives have every reason to fight on. As we have seen, the Act delegates the most important matters concerning professional standards to the POB. From a political perspective, those matters remain contestable. Enormous rents remain at stake, in respect of both auditing services and outside consulting. The political climate remains volatile, creating openings in which the voice of influence can effectively be raised. And even as Sarbanes-Oxley delegates this core subject matter and contains relatively few significant self-executing rules, it probably still has more regulatory bite than many of the Congressmen who voted in its favor really desired. It was passed by a Congress in haste, frightened of negative elective consequences stemming from the compounding of the Enron disaster by the WorldCom accounting scandal (and bankruptcy) of the summer of 2002 . The Act was signed by a President activated by much the same political calculation. ${ }^{40}$ Ordinarily, many of these actors would have been more accommodating of the interests of the accounting profession and its clients. ${ }^{41}$

38. Chairman Arthur Levitt's memoir provides an excellent summary. See ARthur Levitt, Take on the Street: What Wall Street and Corporate America Don't Want You to Know, What You Can Do to Fight Back 109-15 (2002).

39. See id. at 115-39.

40. See Statement by President George W. Bush upon signing H.R. 3763, 38 WrLy. Comp. Pres. Doc. 1286, 1286 (July 30, 2002), available at www.gpoaccess. gov/executive.html\#presidential ("The Act adopts tough new provisions to deter and punish corporate and accounting fraud and corruption, ensure justice for wrong doers, and protect the interests of workers and shareholders.").

41. See Mike McNamee, Will Pill Pick an Accounting Watchdog Who Can Bite?, Bus. Wk., Sept. 2, 2002, at 47 (commenting that SEC Chairman Harvey Pitt was under pressure to "touch all the political bases" when picking new candidate to head POB). Congressman Michael G. Oxley, the Oxley of Sarbanes-Oxley, went right to work with the accounting lobby to undercut the POB. See Editorial, Killing 
It comes as no surprise that the accounting profession continued to contest the substance of the new regime by asking for a POB that would accommodate its interests. There resulted, in October and November of 2002, one of the more sordid moments in the whole series of scandals. Harvey Pitt, the SEC Chairman, nominated William Webster to be the POB chair. Webster, a well-known actor on Washington's regulatory stage, was thought to bring an accommodating disposition respecting vested interests. Unfortunately, his cooperative disposition already had manifested itself in a questionable boardroom judgment. As a member of an audit committee, Webster had voted to fire an audit firm that had raised questions about the propriety of management treatments. This embarrassing fact, privately disclosed by Webster to Pitt, was then concealed by Pitt from other members of the Commission. Revelation of the nondisclosure triggered a pre-election furor. Webster resigned from consideration, ${ }^{42}$ and Pitt made public his resignation from his post as soon as the polls closed on election day. ${ }^{43} \mathrm{~A}$ substitute nominee was not named for almost six months. ${ }^{44}$ That nominee, William J. McDonough, former president of the Federal Reserve Bank of New York, has a reputation for toughness and integrity. ${ }^{45}$ But, because delay has a value, and the nominee has no ties to the agenda of corporate governance activists, the round must be scored in the industry's favor.

The Final Four firms, pressed to protect their franchise and accompanying rents, can be expected to continue this rear guard action. The final outcome remains anybody's guess. For the present, one can only say that Sarbanes-Oxley's regulatory delegation makes possible a meaningful realignment of the auditors' incentives of auditors without providing a circumstantial guarantee that the realignment ever actually occurs. ${ }^{46}$

Reform Behind Closed Doors, Bus. WK., Oct. 21, 2002, at 174 (insinuating that Congressman Oxley's effort to block appointment of tough reformer John Biggs was result of lobbyist pressure).

42. See Don A. Moore, An Honest Account, Wall Sт. J., Nov. 13, 2002, at A24 (explaining circumstances surrounding William Webster's resignation).

43. For commentary on these sorry events, see, for example, Jeanne Cummings et al., Rapid Exit: SEC's Pitt Resigns Amid Controversy Over Webster Job, WALL. ST. J., Nov. 6, 2002, at A4; Robert Kuttner, So Much for Cracking Down on the Accountants, Bus. WK., Nov. 18, 2002, at 24; Alan Murray, Webster Is Symptom of the Very Disease He's Meant to Cure, WALl ST. J., Nov. 12, 2002, at A4; Michael Schroeder, Leading the News: Webster Makes It Official and Quits Accounting Board, WALL. ST. J., Nov. 13, 2002, at A3.

44. Charles D. Niemeier was named acting chair of the POB in January 2003. See Cassell Bryan-Low \& Michael Schroeder, SEC Names Niemeier Acting Head of Accounting-Oversight Board, WALL ST. J., Jan. 9, 2003, at C10. The POB's first official action was to vote its members a salary of $\$ 452,000$. See David Rogers, Big Salaries for Oversight Panel Are Questioned on Capitol Hill, WALL. ST. J., Jan. 1, 2003, at A4.

45. See Deborah Solomon \&c Cassell Bryan-Low, 'Tough' Cop for Accounting Beat, Wal. St. J., Apr. 16, 2003, at C1.

46. Congress, having thus delegated the hard questions about auditor independence, proceeds in section 301 to place them in the near term into the lap of the audit committee. Sarbanes-Oxley Act $\$ 301$ provides in part: 
SEC. 301. PUBLIC COMPANY AUDIT COMMITTEES.

Section 10A of the Securities Exchange Act of 1934 (15 U.S.C. 78f) is amended by adding at the end the following:

(m) STANDARDS RELATING TO AUDIT COMMITTEES.-

(2) RESPONSIBILITIES RELATING TO REGISTERED PUBLIC AC COUNTING FIRMS.-The audit committee of each issuer, in its capacity as a committee of the board of directors, shall be directly responsible for the appointment, compensation, and oversight of the work of any registered public accounting firm employed by that issuer (including resolution of disagreements between management and the auditor regarding financial reporting) for the purpose of preparing or issuing an audit report or related work, and each such registered public accounting firm shall report directly to the audit committee.

(3) INDEPENDENCE.-

(A) IN GENERAL.-Each member of the audit committee of the issuer shall be a member of the board of directors of the issuer, and shall otherwise be independent.

(B) CRITERIA.-In order to be considered to be independent for purposes of this paragraph, a member of an audit committee of an issuer may not, other than in his or her capacity as a member of the audit committee, the board of directors, or any other board committee-

(i) accept any consulting, advisory, or other compensatory fee from the issuer; or

(ii) be an affiliated person of the issuer or any subsidiary thereof.

...

“(5) AUTHORITY TO ENGAGE ADVISERS.-Each audit committee shall have the authority to engage independent counsel and other advisers, as it determines necessary to carry out its duties.

“(6) FUNDING.-Each issuer shall provide for appropriate funding, as determined by the audit committee, in its capacity as a committee of the board of directors, for payment of compensation-

"(A) to the registered public accounting firm employed by the issuer for the purpose of rendering or issuing an audit report; and

"(B) to any advisers employed by the audit committee under paragraph (5).”.

Sarbanes-Oxley Act of 2002, Pub. L. No. 107-204, § 301, 116 Stat. 745, 775-77.

With these provisions the statute makes a direct contribution to the accounting practice. Two exercises of management's business judgment lie at the heart of the auditing problem-its selection of the firm's accounting treatments and its selection of the reviewing auditor. Section 301 reconstructs the context in which these choices are made. It takes three steps: First, it accords the audit committee "direct" responsibility for hiring the auditor; second, it vests the audit committee with the power to resolve disputes between the auditor and management; and third, it requires that the audit committee have authority to hire independent counsel and advisors.

A significant opportunity is presented. Section 301 modifies the monitoring model of the board of directors to import a measure of adversity into the boardroom. With section 301 we at last see a move in that direction-a move to a model of an independent director with clear cut agenda control and decisional authority, along with independent sources of support and expertise. This model heretofore has been a policy fantasy, described over and over in generations of articles.

As deployed here, the model approaches the core of the problem, first by getting the auditor appointment and retention decision out of management's hands, and second, by taking the final decision on treatments out of management's hands. The auditor gets to take a step beyond communicative action (and 


\section{Rules versus Principles}

Sarbanes-Oxley addresses a complex professional problem. Some of the problem lies in the form and content of GAAP itself. Most of the problem, however, concerns relations between auditors and their clients and lies at the level of process. Management, and not the auditor, decides on accounting treatments. ${ }^{47}$ It follows in theory that auditors should be the most independent and adversary of professionals. Unfortunately, in practice, our auditors' corporate clients have captured them to a degree even more marked than the degree to which the same corporate clients have captured their lawyers. This situation follows from multiple causes. Prime among them are consulting rents, employment opportunities and industry concentration. ${ }^{48}$ Now, had the Congress wanted to fix the problem, it could have drafted a statute that imposed separation between audit firms and all forms of business consulting. Separation would have stopped the rent flows so as to realign the incentives of auditors and ameliorate their capture by the client interest. Sarbanes-Oxley, more cautiously opts for gradual audit reform, facilitating reform without ensuring it, leaving it to the POB and the SEC to address (or finesse) the problem of industry capture. Having opted for gradualism, the Act's drafters probably had no alternative but to delegate.

Sarbanes-Oxley only stumbles into outright error when it allocates the blame for the disaster equally to substance and to process, to GAAP and to FASB, in addition to the audit firms and their clients. This part of this Article asserts that the error, embedded in Sarbanes-Oxley's commendation of principles-based accounting, potentially could aggravate the crisis of confidence.

In theory, there need be nothing objectionable in an initiative that privileges principles over rules in the articulation of accounting standards (or, for that matter, any other regulation). With principles or, in lawyer's parlance, "standards," the regulator brings more finesse to the application

the alternative of giving up the client) to take an objection about a treatment to an arbitration body, a body that conveniently also happens to be the hiring and firing agent. The committee, with its own expert advice, will be in a position to trump overly aggressive treatments. Since the auditor looks to the committee rather than the top brass as its employer, it at least has some incentive to raise objections. Indeed, the committee does not have to sit back and wait for a dispute. Under section 203 of the Act, the auditor not only has to deliver to the committee the schedule of unadjusted differences, but also has to report on all treatment alternatives discussed with management, their ramifications and the auditor's preference.

Will the new scheme work? It certainly cannot hurt. And, if consulting firms outside of the Final Four firms can gather in enough accounting and auditing expertise, it certainly can help.

47. The leading discussion of the resulting incentive problem in the legal literature is Melvin A. Eisenberg, Legal Models of Management Structure in the Modern Corporation: Officers, Directors and Accountants, 63 CAL. L. REv. 375 (1975). Eisenberg's critique continues to resonate in 2003.

48. See id. at 425-26 (noting accountants are under irresistible pressure to go along with marginal principles). 
of law to fact than occurs with rules. The principle announces a broadbrush directive in the expectation that regulatory particulars will derive from law-to-fact applications over time. In theory, regulations designed this way keep regulators in closer touch with ultimate regulatory objectives even as they allow for variations in the facts of the cases. In contrast, rulebased systems tend toward formalism, with the statement of the rule dominating over both the purpose at hand and the particulars of a given case. Because no system of rules ever can anticipate all the cases, rules need to be accompanied by backstop standards in any event. If they are not, then formalism can be employed to subvert the regulatory purpose as the regulated actors devise strategies of evasion.

The problem respecting principles and rules and GAAP does not directly implicate either the theoretical advantages of principles or the theoretical shortcomings of rules. It instead concerns the process context in which issuers and auditors apply both rules and standards. So long as we lack confidence in management incentives respecting accounting treatments and doubt that auditors are independent of management interests, we have no actor plausibly positioned to make the delicate law-to-fact determinations called for in a principles-based system. If the regulator is not neutral, then a principle always can be manipulated in favor of the presentation that suits management interests. The principle does not itself import incentive compatibility. Accounting rules, with all their flaws, will continue to be the best choice in a second-best world so long as they constrain managers and auditors most of the time. Sarbanes-Oxley accordingly moves too quickly in pushing FASB and the SEC in the direction of principles. Principles-based accounting may work well in other corporate governance systems or in our own system at some future time. But the incentive problems have to be solved first.

\section{A. The Case for Regulating GAAP}

Just as principles are not objectionable in the abstract, so can no objection be raised in the abstract to the proposition, embodied in SarbanesOxley, of aggressive federal intervention respecting the terms of GAAP. ${ }^{49}$ The same incentive problems that make principles-based accounting a bad choice in the present context make it all the more necessary for Congress and the SEC to take a proactive oversight role. GAAP has very close formative ties to the profession that purveys it, ties even closer than those between legislatures and judges, and the legal professionals who advise corporate clients. Government mandates dictate much of the advice lawyers give to clients; the government, although heavily populated with lawyers, at least operates at arm's length from the legal profession.

49. The SEC already has the power to impose accounting rules. The SEC exercises its power only rarely, preferring to leave the job to FASB, which acts under the threat of intervention should the SEC's preferences not be satisfied. See David R. Herwitz \& Matthew J. Barrett, Materials on Accounting for LawYERS 146 (3d ed. 2001). 
Accounting works differently, operating like a guild both at the legislative and at the professional level. Auditors apply law generated within their own profession, operating at closer quarters with the pertinent lawmaking institutions than do lawyers.

The governance structure of FASB demonstrates this proximity. At first glance we see a structure designed to prevent the big auditing firms from dominating the body that makes GAAP. No more than three of FASB's seven seats go to public accountants, with the remaining four being taken by two corporate executives, one financial analyst and one academic. ${ }^{50}$ On further consideration, however, the four-to-three split does not provide a credible guarantee against special interest influence. Recall that the incentive problem stems from management's purchase of the auditor's loyalty. Auditors who want to please accordingly have a community of interest with their audit clients on most hot button issues. FASB, by coupling three auditors with two corporate executives, ensures that the community of interests has a five-to-two voting advantage. FASB also is a very small shop, with a staff of only forty-five. ${ }^{51}$ Add it all up, and a profile of robust institutional independence does not emerge.

Despite this structural weakness, FASB has conducted itself admirably in recent years, taking positions opposed to those of management and the audit profession on key issues like the treatment of good will arising in mergers and management stock options. ${ }^{52}$ So the present point is not that management and professional interests can be expected to have captured most of GAAP most of the time. The point instead is that no institutional mechanism ensures that the public interest trumps the interests of audit firms and their clients in GAAP's promulgation.

Asymmetries of information and methodological wherewithal further contribute to the problem. GAAP is a body of law structurally shielded from outside inspection. Monitoring GAAP is difficult-to stay abreast of substantive issues in accounting is to be a member of the guild in the first place.

Solidarity within the accounting profession also enhances the case for outside regulation of GAAP. Amongst the multitude of talking heads that provided the media with its sound bites during the corporate crisis of 2002, how many were partners in the big accounting firms? The reader will be hard pressed to recall a single audit partner participating in rough and tumble policy discussions respecting the profession and the regula-

\section{See id. at 154 .}

51. See id. For funding, it has had to rely on the charitable support of the big firms, along with a trickle of revenues from publication sales. See id. Meanwhile, the Emerging Issues Task Force (EITF), which since 1984 has had the job of pronouncing on cutting-edge requests for advice on appropriate treatments, is a group comprised almost entirely of representatives of the large firms. See id. at 157.

52. LevITr, supra note 38 , at $106-15$. 
tions it applies. ${ }^{53}$ This profession closes ranks when a major conflict breaks out between it and the rest of the society and economy. Professional solidarity is in turn augmented by industry concentration: As of this writing there are only four firms left with the wherewithal to conduct audits of large capitalization companies. ${ }^{54}$ In a universe of four organizations, discipline is easily maintained.

The legal profession, with all its faults, displays no comparable solidarity. For every lawyer who closes ranks with a corporate client, there is another lawyer looking to bring suit against that first lawyer's client or, alternatively, to get the legislature to authorize a lawsuit. When the corporation's lawyer goes to Capitol Hill to get the client protective legislation, the trial lawyers also are there, working the other side. When lawyers advocate for their clients in public, they are understood to be acting in a special role. Any representations they make on a clients' behalf concerning the state of the law are greeted with skepticism. Indeed, critique usually is guaranteed, for a second lawyer will be charged with articulating the opposing view.

Accountants operate differently as a profession, even as they more and more resemble lawyers playing an advocacy role for their clients. Where with lawyers the advocacy appears in briefs and memoranda of law, with accounting the advocacy merges into the numbers reported on the clients' certified financials. Readers of financial reports are not on notice to bring skepticism to bear, at least until very recently. Even if they proceed cautiously, they get only indirect means, within the reports' four corners, with which to sort numbers influenced by advocacy from harder numbers uninfluenced by management's agenda. This does not go to say that financial reports always are taken at face value. In theory, Wall Street's financial analysts play the critical function. Unfortunately, in recent practice, they too have lacked the incentive to criticize. ${ }^{55}$ Nor can we expect critique to arise from within the accounting profession, not one faction of which has a financial stake in articulating adversary positions. The entire burden of critique and correction has devolved on FASB, the SEC accounting office and a handful of academics.

In sum, structural reasons should keep us suspicious of GAAP as well as of financial reports issued pursuant to it. It follows that both may need to be addressed in a meaningful post-Enron reform program.

53. We must put to one side Arthur Andersen's Joe Berardino, who publicly and unsuccessfully acted out the role of the CEO trying to quell an organizational conflagration.

54. See Levitr, supra note 38 (discussing recent history of large public accounting firms).

55. The incentive problem stems from underwriting and other rent streams flowing from the issuers of financial reports to the employers of analysts. It is not clear that the problem admits of an easy solution. Absent that corrupting rent flow, it is not clear that resources exist to support an adequate flow of critical analysis. 


\section{B. Enron, GAAP, Regulatory Arbitrage and Strategic Evasion}

Misleading treatments of off-balance sheet entities lie at the Enron scandal's core. Dissatisfaction with the applicable rules and their formover-substance approach has been widespread. FASB itself consistently has numbered among the dissatisfied voices, for two decades, keeping open a project inquiring into an alternative approach with a principlesbased definition of control. ${ }^{56}$ Unfortunately, FASB abandoned that project as a failure even as the Enron scandal was breaking. After the scandal broke, FASB responded to widespread criticism with a couple of Enronresponsive exposure drafts. ${ }^{57}$ The body responsible for GAAP thereby implicitly admitted that its rules had failed.

FASB's admission of a rule failure tells us more about its weakness as a political player than it does about the operation of GAAP. ${ }^{58}$ In acting out the role of a deficient lawmaker, FASB confirms a conventional wisdom circulating in the wake of the scandal. That is, the assumption that there must have been something wrong with the rules or a disaster this big never could have occurred. The story has it that Enron exploited highly technical but flawed accounting rules in setting up and accounting for sham transactions. The transactions exploited the rules governing Special Purpose Entities (SPEs). By carefully but cynically hewing to the rules, Enron managed to overstate its earnings materially. Had the rules been better drafted, Enron would have been forced to consolidate the results of the sham SPEs with its own results. Consolidation in turn would have deprived Enron of the opportunity to misstate its earnings. ${ }^{59}$

56. See Consolidated Financial Statements: Purpose and Policy, Proposed Statement of Financial Accounting Standards No. 194-B (Fin. Accounting Standards Bd. 1999) (proposed Feb. 23, 1999).

57. See Consolidation of Certain Special. Purpose Entrties-An InterpreTATION OF ARB No. 51, Proposed Statement of Financial Accounting Standards (Fin. Accounting Standards Bd. 2002) (proposed July 1, 2002). This draft deals with SPEs and would have caused the consolidation of Enron's LJM 1 and 2. It also increases the outside equity requirement to ten percent for a residual class of SPEs that would have included those in question. A second initiative addresses disclosures of guarantees, on the purport that the present rules lack clarity. See GUARANTOR's ACcounting and Disclosure Requirements for Guarantees, Including INDIRECT GUARANTEES OF INDEBTEDNESS OF OTHERS, Interpretation of Financial Accounting Standards No. 45 (Fin. Accounting Standards Bd.) (Nov. 25, 2002).

58. Significantly, reporting companies and the big accounting firms, notably including Andersen and Enron, vigorously opposed FASB's consolidation project, criticizing the FASB's draft as unworkable. See Steve Burkholder, Accounting: Outlook 2002-Enron Sets Agenda of Regulators, Rulemakers; FASB Forges on With Projects, 34 SEC. REc. \& L. RE.P. (BNA) 214, 215-16 (2002) (noting that strong criticism has prevented FASB from issuing comprehensive consolidations accounting standards); Glenn R. Simpson, Power Play: Deals That Took Enron Under Had Many Supporters, WALL ST. J., Apr. 10, 2002, at A1, A13 (asserting that FASB shelved its project amid industry criticism).

59. One finds this story casually mentioned as accepted wisdom in the pages of the New York Times at the end of 2002. See Kurt Eichenwald, A Higher Standard for Corporate Advice, N.Y. Times, Dec. 23, 2002, at A1, A20 (quoting Professor Frank Partnoy as follows: "Enron was following the letter of the law in nearly all of its 
Generalizing from the story, GAAP failed in respect of Enron because it regulates by rule, articulating layer on layer of precise instructions. Such precise, rule-based systems of regulation are always open to manipulation in the hands of clever and high-priced accountants and lawyers pursuing regulatory arbitrage. Had GAAP followed from a different regulatory strategy, articulating general substantive principles respecting consolidation and SPEs, there would have been no loophole through which the bad actors at Enron could have driven their fleet of sham SPE trucks.

The story is accurate in one respect-the rules respecting accounting for transactions with SPEs are badly drafted and incomplete. But in all other respects the story is nonsense. Enron, in fact, did not follow the rules. ${ }^{60} \mathrm{Had}$ it done so, the substance of all of its questionable dealings with SPEs would have been disclosed in its financial statements. It follows that the rules did not fail. This is a case less of regulatory arbitrage than of strategic evasion. The failure lay with actors at Enron and its auditor, Arthur Andersen.

It is true that the SPE transactions at the heart of the Enron scandal emerged from an exhaustive planning process and that they were designed to comply with the rules even as they exploited the rules' structural weaknesses. Under FAS No. 140, issued in 2000, transfers of financial assets to SPEs are treated as sales by the transferor firm so long as, among other things, equity interests in the SPE are not returned as consideration for the assets transferred and the SPE gets control of the assets with the right to pledge or exchange them. ${ }^{61}$ To comply with the standard, all one must do is have the SPE vehicle meet the requirement of an outside equity interest with an investment constituting three percent of the value of the assets transferred to the SPEs. ${ }^{62}$ It also is true that at the time Enron set up the critical "LJM I" and "LJM II" SPEs and entered into transactions with them, the transactions arguably complied with the rules. But, as the Powers Report details at length, the transaction structures had intrinsic flaws and went out of compliance with the three percent rule very soon after the transactions closed. ${ }^{63}$ Had Enron followed the rules at that point, it would have been forced to consolidate the SPEs into its financials.

deals. It is fair to say that the most serious allegations of criminal wrongdoing at Enron had almost nothing to do with the company's collapse. Instead it was the type of transaction that is still legal"). For further discussion of this viewpoint, see Frank Partnoy, A Revisionist View of Enron and the Sudden Death of "May", 48 VILL. L. REV. (forthcoming 2003).

60. For further discussion of FASB's three percent rule governing SPEs, see infra notes 61-72 and accompanying text.

61. Accounting for Transfers and Servicing of Financial Assets and ExTINGUISHMENTS of LiabilitiEs, Summary of Statement of Financial Accounting Standards No. 140, II 29, 34 (Fin. Accounting Standards Bd. 2000) [hereinafter SFAS 140].

62. See id.

63. See William C. Powers, Jr. et al., Report of Investigation by the SpeCial InVestigative Committee of the Board of Directors of Enron CorP., 2002 WL 198018. 
Had the SPEs been consolidated, the results of transactions with the SPEs would have dropped off of both the balance sheet and income statement, with the result that Enron would not have been able to pump up its net earnings with revenues and gains from its SPE transactions. The financials, of course, were not consolidated, but not because of the rules. Instead, Enron's managers resorted to the old fashioned expedient of concealment.

Significantly, Enron's financials would have been out of compliance with GAAP even with its SPEs in compliance with the rules on consolidation at all times. Under FAS No. 57, contracts between Enron and the LJM-related SPEs were "related party transactions." This category includes transactions with a counterparty whose policies are sufficiently influenced by the first party so as to prevent one of the parties from fully pursuing its own interests. Given such a tie, special footnote descriptions of the transactions are required, including dollar amount impacts on reported earnings. ${ }^{64}$ Such footnote disclosures would have provided investors with the substantive equivalent of a set of consolidated reports. But, of course, Enron did not wish to make clear the truth respecting its earnings, and its cooperative auditor failed to insist that it follow the rules on related party transactions.

A similar situation prevailed with the second reporting failure at the core of the Enron scandal. The straw that broke the camel's back and forced Enron into bankruptcy in December 2001 was its last minute revelation of $\$ 4$ billion of unreported contingent guarantees of obligations of unconsolidated equity affiliates, obligations about to come due. ${ }^{65}$ As to these obligations GAAP has a definite instruction. To guarantee an equity affiliate's obligations is to take the disclosure treatment out of the parentsubsidiary or parent-investee context for treatment under the rules on contingent losses. Those rules state a clear cut case for disclosure. Under FAS No. 5, loss contingencies are divided into three classes-probable, reasonably possible and remote. Probable losses should be accrued; reasonably possible losses should be disclosed in footnotes with information as to nature and magnitude; remote losses need not be disclosed. There is a separate rule for financial guarantees. With guarantees, even if the possibility of loss is remote, there must be footnote disclosure as to nature and amount. ${ }^{66}$ Enron failed to make those disclosures because they would

64. See Related Party Disclosures, Statement of Financial Accounting Standards No. 57 II 2, 24(f) (Fin. Accounting Standards Bd. 1982).

65. See Bratton, supra note 1, at 1320-25 (detailing Enron's collapse due to high risk and hidden financial strategies).

66. See Accounting for Contingencies, Statement of Financial Accounting Standard No. 5 II 5 (Fin. Accounting Standards Bd. 1975). Paragraph 12 reads: "The Board concludes that disclosure of [guarantees of indebtedness of others and others that in substance have the same characteristic] shall be continued. The disclosure shall include the nature and amount of the guarantee." Id. I 12; see also Disclosure of IndiRect Guarantees of Indebtedness of OTHERs, Interpretation of Financial Accounting Standard No. 34 (Fin. Accounting Standards Bd. 1981); 
have meant a rating agency downgrade from investment grade status, and Enron needed an investment grade rating to run its trading business. As a result, Enron materially understated its obligations as guarantor, perpetrating an old fashioned financial fraud by concealment. It comes as no surprise that thus stated, Enron's financials were not in compliance with GAAP. ${ }^{67}$

The conventional wisdom errs in a second respect as well. The story blames the complex rules that determine accounting for SPE transactions. It asserts that had FASB adopted a principles-based approach to consolidation of related entity financial statements, Enron would have been disabled from perpetrating its fraud. Unfortunately for the story, the complex rules governing SPEs in FAS No. 140 apply only to mainstream transactions, like the securitization of pools of mortgages. Enron's SPE transactions did not flow in the mainstream governed by FAS No. 140. They instead fell into a category of "other" SPE transactions not covered directly by a FASB rule. ${ }^{68}$ For transactions in this residual category, the critical requirement is a minimum outside equity investment. As to this requirement, the accounting firms have used a three percent rule of thumb test, derived from an SEC accounting opinion. ${ }^{69}$ This approach dates from a 1991 letter of the Chief Accountant of the SEC issued in respect of a leasing transaction. ${ }^{70}$ To read the letter is to see that the SEC required three percent outside equity on the facts of the case and never intended three percent to be taken as a one-size-fits-all test. ${ }^{71}$ Since 1991, the SEC has insisted repeatedly that there is no three percent test and that the level of outside equity funding for a qualifying SPE in the residual

Herwitz \& BarretT, supra note 49, at 617-20. Note that under SFAS No. 140, a separate recourse obligation against the transferor of an asset to an SPE in respect of reimbursement for losses on the underlying portfolio (as opposed to a derivative arrangement) continues to be treated under SFAS No. 5. That is, the transferor makes an ongoing assessment of the amount of the loss in its financials rather than adjusting the obligation to fair value and reporting it in income. See SFAS 140 , supra note $61,129$.

67. Having violated GAAP, Enron's financials, therefore, were per se misleading for securities law purposes. See Administrative Policy on Financial Statements, Accounting Series Release No. 4, 11 Fed. Reg. 10,913 (Apr. 25, 1938), codified at Codification of Financial Reporting Policies $\$ 101$, reprinted in [1937-1982 Transfer Binder] 7 Fed. Sec. L. Rep. (CCH) I 72,005, at 62,101 (providing SEC's standard for misleading financial statements).

68. See SFAS 140, supra note 61, I 34.

69. The GaAP authorities are Transactions involving Special Purpose EntITIES, Statement of Financial Accounting Standards EITF Topic D-14 (Fin. Accounting Standards Bd. 2002); Impact of Nonsubstantive Lessors, Residual Value Guarantees and Other Provisions in Leasing Transactions, Statement of Financial Accounting Standards EITF Topic 96-21 (Fin. Accounting Standards Bd. 2002); Implementation Issues in Accounting for Leasing. Transactions involv. ing SPecial Purpose Entities, Statement of Financial Accounting Standards EITF Topic 96-21 (Fin. Accounting Standards Bd. 2002).

70. See Bratton, supra note 1 , at 1307 n.118.

71. See id. (discussing SEC's insistence that there is no bright-line three percent test). 
category should follow from the nature of the transaction. ${ }^{72}$ In the SEC's view, the question is not whether sufficient outside equity capital has been invested to ensure the SPE's independence. The outside equity requirement is thus intended not to be a "rule" but a "principle" or "standard" with the amount to be increased or decreased on the facts of the case.

Yet, despite the SEC's jawboning on the matter, the audit firms applied the SEC's outside equity standard as a three percent test, a narrow rule. Certainly this was the operative assumption when Enron planned its SPE transactions.

Contrary to the conventional wisdom, then, the central problem lay not with the rules themselves but with Enron's failure to follow them. The disaster stemmed not from any structural problem with the rules but from Enron's corruption and its auditor's incentive problems.

More generally, there can be no denying that practitioners often take advantage of GAAP's rule structures when they design aggressive treatments. Regulatory arbitrage - the practice of structuring an inappropriate transaction so it stays within the bounds set by a rule ${ }^{73}$-is clearly widespread. But these rules-based aggressive treatments, which tend to involve structured finance, leases and (until recently) pooled mergers, do not show up in large numbers on the list of recent accounting restatements. ${ }^{74}$ The reason is that the rules make the treatments GAAP compliant, even as many observers disapprove of the treatments. ${ }^{75}$ Issues still arise for FASB. But the indicated course of action appears to be amendment of rules to adjust their categories to yield reporting results following from the rules' operative principles. Like the Enron accounting restatements, those of other companies follow less from regulatory arbitrage than from strategic noncompliance-action under an interpretation of the law in conflict with the stated interpretation of the regulator. ${ }^{76}$ Neither rules nor standards prevent such conduct, and, as between the two, rules could even have the advantage in deterring it. Meanwhile, in every case of a restatement, GAAP by definition has proved adequate to the job of identifying the misstatement and providing corrective instructions. ${ }^{77}$

72. See Dominick J. Ragone III, Current Accounting Projects, 2000 Conference on SEC Developments (Dec. 4, 2000).

73. See Timothy F. Malloy, Regulation and the Compliance Norm, (Working Paper, 2003) (on file with author).

74. Revenue overstatements make up the largest category of recent restatements, at thirty-nine percent, with cost understatements coming in second at sixteen percent. See GAO RePort, supra note 2, at 18.

75. See Mark W. Nelson, et al., Where Do Companies Attempt Earnings Management, and When Do Auditors Prevent It?, (SSRN Working Paper, June 2000), available at http://www.ssrn.com (showing that auditors pass on these treatments as GAAP compliant).

76. See Malloy, supra note 73.

77. The rule might be over inclusive; that is, it might bring inappropriate transactions into a given zone of treatment. A rule also might be under inclusive; that is, it might allow a transaction that should be included in a treatment category 


\section{Rules and Principles in Theory and in Practice}

In the previous section we saw a standard setting agency, the SEC, articulate a standard and tell the auditors to apply it as such, only to have the auditors instead apply the standard as a rigid numerical rule. The auditors in effect invented a rule where none existed. Why did they do this? To what do we attribute this problem of communication and compliance? The process of answering these questions gives us insight into problems accompanying a principles-based approach to accounting.

\section{The Framework of the Debate}

Auditors in this country like rules. They want more of them. Indeed, the then Big Five accounting firms responded to the Enron crisis by demanding more rules and blaming regulators for failing to supply them. Joe Berardino, the managing partner of the ill-fated Andersen firm, led the charge. The real failure, he said, lay not in his firm's audit but in accounting rules themselves, which permit off-balance sheet financing through SPEs. If something went wrong with Enron's financials, then the rules ought to be rethought. ${ }^{78}$ The burden to effect improvement, said the accounting firms, lay on the SEC rather than on their own audit practices. Accordingly, to restore confidence, the SEC should supply "immediate guidance" to public companies respecting disclosure of off-balance sheet transactions, over the counter derivative contracts, and related-party transactions. ${ }^{79}$ In particular, the SEC should require issuers to provide more details respecting off-balance sheet guarantees, commitments, lease and debt arrangements that could impact on credit ratings, earnings, cash flow or stock price. ${ }^{80}$

Commentators from outside the accounting industry quickly countered with the opposite complaint. The problem with GAAP, they said, lies in its exhaustive check-the-box system of rules. Auditors apply the rules mechanically, ignoring the substance of the clients' transactions. ${ }^{81}$ The rule-based system of regulation fosters the culture of noncompliance, as the actors regulated by the rules invest in schemes of evasion. Harvey Pitt, the ill-fated SEC chairman, joined this responsive chorus:

Present-day accounting standards are cumbersome and offer far too detailed prescriptive requirements for companies and their

to be structured so as not to be included. See Cass R. Sunstein, Problems with Rules, 83 CAL. L. Rev. 953, 995 (1995).

78. See Joe Berardino, Enron: A Wake-Up Call, WALL ST. J., Dec. 4, 2001, at A18.

79. See Judith Burns \& Michael Schroeder, Accounting Firms Ask SEC for PostEnron Guide, WALL ST. J., Jan. 7, 2002, at A16.

80. See id.

81. See Steve Liesman, SEC Accounting Cop's Warning: Playing by Rules May Not Ward Off Fraud Issues, WALL ST. J., Feb. 12, 2002, at C1 (discussing voluminous accounting standards to shield auditors from liability); Leaders: The Lessons from Enron, ECONOMIST, Feb. 9, 2002, at 9-10 (finding accounting standards, in some areas, "so prescriptive that they have lost sight of broader principles"). 
accountants to follow.... We seek to move toward a principlesbased set of accounting standards, where mere compliance with technical prescriptions is neither sufficient nor the objective. ${ }^{82}$

Pitt's criticism eventually found its way into Sarbanes-Oxley's section $108(d)$, which directs an inquiry into the feasibility of a principles-based system.

A disturbing commonality ties the audit firms' request for more rules and the responsive request for principles. Even as the discussants take opposite sides concerning the drafting of GAAP, they come together in blaming GAAP for the current crisis. In the case of the accounting firms, denial and avoidance appear to be at work: To the extent blame attaches to the rules, attention is deflected from incentive problems tied to consulting rents. More particularly, to look at Enron and the other scandals is to see auditors going beyond technical manipulation to opine favorably on material misstatements that clearly violate the rules. The negative implications for current audit practice are staggering, so much so as to prompt an attack on the rules as an affirmative defense. The same motivation seems to have figured into Harvey Pitt's argument of the opposite side of the case. Pitt's original reform program included a toothless accounting oversight regime, lambasted for its overprotection of the audit firms, which happened to be Pitt's former clients. ${ }^{83}$

The argument for principles also dovetails with the interests of certain marketplace actors. Because International Accounting Standards (IAS), a body of accounting principles widely used by firms outside of the United States, is a principles-based regime, the argument for principles in GAAP overlaps the argument in favor of SEC acceptance of financial reporting pursuant to IAS. Thus, we can expect to hear the argument from every intermediary on Wall Street who would like to see more rents from foreign listing business, along with actors in the European and Asian offices of the Final Four firms. We also can expect to hear it from Europeans and Asians who, during the past decade, have listened in exasperation to

82. Testimony Concerning the Corporate and Auditing Accountability, Responsibility, and Transparency Act; Hearing Before the House Comm. on Fin. Serv., 107th Cong. (Mar. 20, 2002) (statement of Harvey L. Pitt, Chairman, SEC), available at http:// www.sec.gov/news/testimony/032002tshlp.htm (last visited Apr. 11, 2003).

83. Pitt proposed an independent regulatory body, governed by an independent board, to be effectuated only with the cooperation of the Big Five. See Michael Schroeder, SEC Proposes Accounting Disciplinary Body, WALL ST. J., Jan. 17, 2002, at C1. Critics pounced immediately, arguing that too many CPAs would be present in the proposed enforcement structure. See Diana B. Henriques, Policing the Accountants with a Watchdog from the Accounting Business, N.Y. TIMEs, Jan. 21, 2002, at A12. The critics claimed that the defendants could stall the process until the completion of overlapping litigation and that the absence of subpoena power will disable the enforcers from gathering necessary evidence. To import such power, a statute was needed. See Mike McNamee, Pitt's Accounting Fix Leaves a Lot Broke, Bus. WK., Feb. 4, 2002, at 38-39. Indeed, Pitt's proposal did not come close to restoring confidence in the wake of Enron. A statute, Sarbanes-Oxley, had to be drafted. 
Americans claiming evolutionary superiority for the U.S. corporate governance system. ${ }^{84}$ The crisis of confidence in the U.S. markets gives them a welcome opportunity to turn the argument around.

\section{Principles as Rules}

Many make the argument for principles-based accounting absent private agenda items, motivated by the view that principles will work better than rules and could materially improve the quality of financial reporting. In evaluating the argument, the first question that arises concerns the meaning of "principles." Principles are accounting standards more broadly stated, ignoring particulars of application on their face. Applied literally they can work like rules, rules that impose common treatments across ranges of subject matter differing as to particulars. Applied flexibly, with a view to the purpose behind the statement, principles can enhance the discretion of managers and auditors in the selection of accounting treatments. ${ }^{85}$

To the extent the discussants refer to "principles" as broad-brush statements that would apply as constraining mandates, a couple of results can be predicted. There would indeed be a decrease in the level of reporting detail. At the same time, comparability of treatment across different issuers would be enhanced. But the decrease in complexity implies a concomitant loss of transparency, since commonality of treatment obscures particulars in the economics of differing underlying transactions. ${ }^{86}$ In the minds of many observers, these pluses and minuses would net out clearly on the plus side to the extent that the principles' broad-brush statements prohibited whole classes of aggressive treatments, substituting strong conservative mandates. Note that on this scenario, "principles" would be better described as tough, general rules. ${ }^{87}$

A question arises: How likely in the present political and institutional context is it that reporting companies, their auditors and their friends in Washington would permit FASB to use principles-based accounting to usher in a new era of strict treatments? The answer must be, very unlikely.

84. See, e.g., David P. Hale, Saving the Banks: Learning from Germany and Japan, Wall. St. J., Feb. 4, 1991, at A10.

85. Under the flexible approach, firms in the same industry could apply different treatments, with the accountants tailoring the general principles to the reporting firm's particular needs. For a description, see Joshua Ronen, Post Enron Reform: Financial Statement Insurance and GAAP Re-Visited, 8 Stan. J. L. Bus. \& FIN. 39, 60-65 (2002).

86. The comments in the text draw on FASB, Principles Approach, supra note 7 , at 7 .

87. FASB's proposal respecting principles, in effect, warns audit firms and issuers of this when it points out that principles will mean more volatility in reported earnings figures. See id. at 7-8. 


\section{Principles as Flexible Standards}

If principles-based accounting does not hold out a new era of strict treatments, then it follows that a move to principles means a move to the general but flexible guidelines that lawyers call "standards." 88 To the policy argument for principles as standards, I offer four points in rebuttal.

\section{a. GAAP Already Combines Standards and Rules}

The first rebuttal admits the correctness of the view controverted: Yes, an effective system of accounting principles must build on principles and cannot be constructed entirely of rules. This point is so fundamental that we can even prove it by reference to GAAP. GAAP is already built on broad and powerful principles, seven of them: (1) historical cost, (2) objectivity or verifiability, (3) revenue recognition, (4) matching, (5) consistency, (6) full disclosure and (7) relevance or fair value. ${ }^{89}$ FASB expounds on the principles' meaning in a series of Concepts Statements. ${ }^{90}$

The last principle on the list, fair value, lately has been growing in importance at the expense of the first two on the list, historical cost and verifiability. ${ }^{91}$ Tension results-there is no way to have a system requiring verifiable numbers and at the same time offering fair value figures. That tension is being resolved in favor of fair value, as GAAP moves away from a mandate that all reported numbers be hard numbers toward a system that includes many numbers that result from judgment calls, but that, in theory, offer a better picture of the present value of the firm. ${ }^{92}$ Other tensions come into the picture when we reference two modifying conventions-materiality, which lets the auditor disregard minor misappli-

88. Duncan Kennedy offers the classic description of standards in American jurisprudence. See generally Duncan Kennedy, Form and Substance in Private Law Adjudication, 89 Harv. L. Rev. 1685 (1976). Harvey Pitt and other accounting principles advocates would have been well advised to read it.

89. See Herwitz \& Barrett, supra note 49, at 67-70.

90. For FASB's discussion of these in the context of the principles-based accounting movement of 2002, see FASB, PrinCiPles APProach, supra note 7, at 5-7.

91. See generally, Preliminary Views on Major Issues Related to Reporting Financial Instruments and Certain Related Assets and Liabilities at Fair VAlue (Fin. Accounting Standards Bd., Dec. 14, 1999); Stanley Siegel, The Coming Revolution in Accounting: The Emergence of Fair Value as the Fundamental Principle of GAAP, 42 Wayne L. Rev. 1839 (1996).

92. Note that Sarbanes-Oxley section 108(a) directs FASB to prioritize the consideration of new rules reflecting "emerging accounting principles and changing business practices." See supra note 6 (containing full text of section 108(a)). This presumably means more movement to fair value treatments. Congress overlooks the fact that the same movement certainly played a role in the accounting mess at Enron, where market to market and fair value accounting of its derivative and energy contracts contributed mightily to suspicions about its earnings figures. See The Fall of Enron: How Could it Have Happened?; Hearing Before the Senate Comm. on Gov't Affairs, 107th Cong. 58-74 (Jan. 24, 2002) (statement of Frank Partnoy, Professor of Law, University of San Diego Law School). Common sense indicates that we should readjust the balance in favor of verifiability, at least until the crisis has passed. 
cations of the rules, and conservatism, which counsels understatement in case of doubt. Between historical cost, verifiability and conservatism on the one hand, and fair value and materiality on the other, there's a lot of room for good faith dispute about the best way to state a firm's results.

We begin to see a "principled" reason for GAAP's evolution toward rules. This is the very territory where cost considerations most strongly justify a rule-based approach: GAAP governs homogeneous, recurrent situations where the actors need ex ante instructions and have incentives to invest in compliance. ${ }^{93}$ An across-the-board shift to standards would make sense only if the costs of constant revision of the rules to keep up with unintended applications due to faulty drafting outweighed the benefits of advance specification. GAAP does not appear to lie anywhere near that level of dysfunction.

b. Rules Enable Disempowered Professionals to Say No to their Clients

The present problem lies not with GAAP's mix of rules and principles, which no more mesh like the parts of a machine here than they do any other regulatory context, ${ }^{94}$ but with its context of application. An independent auditor is supposed to make reference GAAP's standards in filling in the inevitable gaps in the rules or in answering questions of interpretation under the rules. Such law-to-fact applications should with some frequency lead the auditor to say no to aggressive treatments chosen by the client, on grounds of full disclosure and conservatism. Sir David Tweedie, Chairman of the International Accounting Standards Board (IASB), stressed the importance of professional judgment in a principlesbased system in recent congressional testimony:

We favour an approach that requires the company and its auditor to take a step back and consider whether the accounting suggested is consistent with the underlying principle. This is not a soft option. Our approach requires both companies and their auditors to exercise professional judgment in the public interest. Our approach requires a strong commitment from preparers to financial statements that provide a faithful representation of all transactions and a strong commitment from auditors to resist client pressures. It will not work without these commitments . . .95

93. See Louis Kaplow, Rules Versus Standards: An Economic Analysis, 42 DukE L.J. 557, 570-77 (1992).

94. See FASB, Principles Approach, supra note 7, at 6.

95. Accounting and Investor Protection Issues Raised by Enron and Other Public Companies: International Accounting Standards and Necessary Reforms to Improve Financial Reporting; Hearing Before the Senate Comm. on Banking, Hous. $\mathcal{E}$ Urban Affairs, 107th Cong. (Feb. 14, 2002) (statement of Sir David Tweedie, Chairman, International Accounting Standards Board), available at http://www.banking.senate.gov/ 02_02hrg/021402/tweedie.htm (last visited Apr. 11, 2003). 
To apply principles in the manner contemplated requires an exercise of judgment, an exercise that captured auditors are disabled from making. Before saying no to a client, our auditors insist on the backing of a precise instruction. This provides an additional explanation for why our system has evolved in a rules-based direction.

Now, auditors only mimic the actions of corporate lawyers in demanding rules. When telling their clients that a course of action is prohibited, lawyers too like to draw from an explicit statutory bar or a case on all fours. That way lawyers denude negative responses of the suggestion that the nay saying stems from the lawyer rather than an external authority. From a compliance point of view, it follows that a standard can work better when the professional dispensing advice is empowered vis a vis the client. Only then will the professional's judgment call on all the facts be respected. Unfortunately, the present balance of power between auditors and clients does not appear to favor the auditor's professional judgment.

\section{c. The Trend to Rules Covers All of Business Law}

The third rebuttal also admits the correctness of the view controverted: Yes, GAAP has become too rule based. The admission is a rebuttal because the same thing has been happening across business law as a whole, which has been evolving away from broad standards and toward precise rules. Business law and lawyers no longer subscribe to the legal realists' view that fact specific adjudication under standards makes law more responsive. ${ }^{96}$ As an example, compare the old Uniform Partnership Act, ${ }^{97}$ drafted early in the twentieth century, with a Revised Uniform Partnership Act, ${ }^{98}$ drafted at the end of the century. The former is a collection of short, general statements. The latter is a labyrinthine affair that looks like it is trying to answer every question that ever came up about partnership governance. Alternatively, one might track the evolution of the UCC and the cases there under over the last three decades. One will find new drafts more and more complicated than the originals and the courts abandoning general ideas like liberal construction ${ }^{99}$ and good faith. ${ }^{100}$ The drafters no longer leave it to the case law to fill in the details.

96. See William W. Bratton, Berle and Means Reconsidered at the Century's Turn, 26 J. Corp. L. 737, 746-47 (2001).

97. See UNIF. P'ship Act, 6 U.L.A. 275 (1914).

98. See Revised Unif. P'ship Act, 6 U.L.A. 1 (1997).

99. See Gregory E. Maggs, Karl Llewellyn's Fading Imprint on the Jurisprudence of the Uniform Commercial Code, 71 U. Colo. L. Rev. 541, 56472 (2000) (describing original UCC collaborators' desire for "purposeful interpretation" of Code provisions).

100. See William W. Bratton, Venture Capital on the Downside: Preferred Stock and Corporate Control, 100 MicH. L. REv. 891, 933-34 (2002) (describing application of good faith within context of interpreting debt and preferred stock agreements). 
Instead they pursue the impossible dream of creating complete sets of instructions, just like the accountants. ${ }^{101}$

Many reasons for the movement to rules can be suggested. Confidence in judicial decision making has declined even as the expense of litigating questions of interpretation has risen. In commercial law contexts the scope of jury control over mixed law and fact questions expanded materially over the latter part of the twentieth century, destabilizing the expectations of business people. There also circulates a general notion that specific instructions import certainty that enhances economic welfare. ${ }^{102}$ Finally, lawyers turn to rules because they want to reduce risk both for themselves and their clients. A rule imports a safe harbor and control of future events where a standard does not.

To sum up, GAAP and business law have moved to rules because auditors, lawyers and clients alike demand clear instructions. They put the burden of clarity on the lawmaker so as to relieve themselves of the burden of making judgments under uncertainty. This is not a healthy development. But the fault lies not in the proliferating rule books. The fault occurs at the point of demand; drafters will continue to generate rulebooks until the demand ceases. Similarly, the resulting rulebooks will be seen as inflexible and burdensome only if the demand lets up.

\section{d. Transparency}

We proceed to the fourth rebuttal. For the sake of argument, let us assume that auditors and clients stop demanding greater rule specificity tomorrow, freeing us to interrogate anew the question of whether GAAP should be articulated in rules or in principles. It is submitted that the case for the status quo-a rule-based approach backed by a small collection of general principles-is materially stronger in respect of accounting than in respect of business law generally. To see why, we go back to the realist case for standards over rules in respect of private law adjudication. That case presupposes that the law-to-fact application is explained and published in a judicial opinion. The reported cases give the practitioner an expanding body of fact sensitive applications, ever better articulating the standard's meaning. Over time, the accumulated case law offers the practitioners a level of certainty not dissimilar to that of a rulebook, even as the standard's flexibility is retained. Meanwhile, the substantive direction of the cases is open for public inspection.

The ongoing rules-based articulation of GAAP by FASB and other public bodies works similarly. ${ }^{103}$ But the application of open-ended ac-

101. For example, compare the original UCC Article 9 and the revised Article 9 on the perfection and priorities of security interests. See U.C.C. $\$ \$ 9-301-9-318$, 3A U.L.A. 859-1037, 3B U.L.A. 33-386 (1972); U.C.C. $\$ \S 9-301-9-342,3$ U.L.A. $154-301(2000)$.

102. I do not endorse the stated proposition.

103. According to FASB, any bias toward rules in contemporary GAAP stems from exactly this sort of law-to-fact development process; as rules are rewritten to 
counting principles by reporting firms and auditors does not. Financial statements and footnotes are very summary documents. Decision making about treatments goes on in a black box, evolving as a matter of practice amongst the insiders. ${ }^{104}$ There is no comparable moment of transparency respecting the law-to-fact application. This diminishes the chance for outside evaluation. The law-to-fact decisions, meanwhile, are not made by judges empowered by the state. They come from the users-the regulated actors themselves-acting with an input of the auditor's professional review. And a professional, even one historically conceived to be in an adversary posture to its client, is in a materially different position from a judge. Adjudicatory authority imports absolute power to say no. The outside professional can only suggest no, on pain of giving up the client. Today's auditors are disinclined even to threaten to walk, much less actually to forego the rent flowing from a given audit engagement. A serious incentive problem results, a problem that makes a move to flexible, openended principles an invitation to disaster.

\section{International Convergence}

The incentive problem tied to audit and consulting rents and the incentive problem tied to the clients' demand for rules are both bound up in the same professional relationship, that between the auditor and the audit client. Client demands appear to have become so intense and consulting opportunities have become so lucrative as to overwhelm the selfregulatory system's traditional incentive bedrock-the auditor's interest in a reputation for conservatism and fidelity to the interests of investors. Given this relational dynamic, Sarbanes-Oxley triggers concerns when in section 108(a) it orders FASB to move toward "international convergence on high quality accounting standards."

FASB compliantly has responded. ${ }^{105}$ Indeed, this is an ongoing process. FASB and IASB have been working together to move accounting toward international convergence for some years now. ${ }^{106}$ As with principlesbased accounting, the proposition of international convergence is unobjectionable in the abstract. The problem concerns potential perverse effects in the context of this country's prevailing institutional arrangements.

Perverse effects could occur to the extent that convergence means adoption of approaches developed against a different relational background. IASB draws primarily on input from accountants in Europe and Asia, where corporate governance works differently than it does here. In this country, separation of ownership and control tends to prevail-stock-

take into account different transactional facts, interpretive opinions accumulate. See FASB, Principles Approach, supra note 7, at 3-4.

104. For a good example of this practice, see supra notes 61-72 and accompanying text for discussion of the three percent rule as applied to SPEs.

105. See Project Updates, Short-term International. Convergence (Fin. Accounting Standards Bd. 2002).

106. See Herwitz \& BarretT, supra note 49, at 161-67. 
holders do not get to tell management what to do and information asymmetries are pronounced. On the continent of Europe, in contrast, control of large capitalization firms tends to be vested in majority or near-majority holdings of stock held in the hands of one, two or a small group of large investors. Blockholding also prevails in the Japanese keiretsu system, although individual and family holders are less prominent. ${ }^{107}$ There, blockholding means aggregations of smaller blocks than in Europe, held by (a) clusters of banks having lending relationships with the issuer firm, and (b) clusters of other nonfinancial companies in many cases in supplier or customer relationships with the issuer. These corporate holders often belong to a formal keiretsu organization along with the issuer, ameliorating collective action problems. ${ }^{108}$

Large block investments imply certain governance benefits for European and Japanese firms. The control shareholder monitors more closely than do our dispersed shareholders and can intervene earlier and more cheaply in the case of management failure. The systems' other primary benefit stems from the blockholders' ability to access information about operations. Reduced information asymmetries permit blockholders to invest more patiently. The longer shareholder time horizon in turn frees management to invest for the long term and creates a more secure environment for firm-specific investments of human capital by the firm's managers. ${ }^{109}$

107. See Curtis J. Milhaupt \& Geoffrey P. Miller, Cooperation, Conflict, and Convergence in Japanese Finance: Evidence from the "Jusen" Problem, 29 LAW \& POL'Y INT'L Bus. 1, 12-13 (1997) (describing how regulatory cartel among government and private sector actors in Japan run according to informal norms and interlinked decision making institutions).

108. The Japanese system also is distinguished for close ties between financial intermediaries and government regulators. See id. at 13-14.

109. See William W. Bratton \& Joseph A. McCahery, Comparative Corporate Governance and the Theory of the Firm: The Case Against Global Cross Reference, 38 Colum. J. Transnat'L L. 213, 224-26 (1999).

There are corresponding costs and limitations. Where the blockholders are firms, internal agency costs can constrain their effectiveness as monitors. Indeed, whatever the identity of the blockholder, its heightened oversight incentive does not appear in practice to result in sharp oversight of management investment policy. Although closer proximity lessens the information asymmetry problem, there is an accompanying increase in management influence and loss of critical objectivity. Freedom to make long-term investments thus often means pursuit of growth in market share at the cost of a suboptimal rate of return on equity investment. Trading markets in blockholder countries tend to be thinner and less transparent than in market system countries, and firms in search of financing encounter a more restricted range of alternatives. Meanwhile, the blockholders themselves give up the benefits of diversification and, given thin trading markets, liquidity and the possibility of easy exit through sale. Finally, there is a shortage of loyalty. Blockholders, having sacrificed diversification and liquidity, extract a return in the form of private benefits yielded through self dealing or insider trading. Legal regimes in blockholder states facilitate this quid pro quo with lax protection 
These differences could lead the auditor-client relationship overseas to have a different character than prevails in this country. With a longer investment time horizon prevailing and no external pressures threatening the insiders' control, there will be less demand for manipulation of current numbers. In consequence, the auditor will be freer to exercise the judgment bound up in the application of a standard. At the same time, the auditor will work in closer proximity to the equity interest, with a constant threat of close scrutiny. Contrariwise, since the blockholder can get direct access to corporate information, it will depend less on the numbers in the audited financials. Conservatism will loom less large as a protective shield for small investors because small investors matter less. Indeed, the blockholder and the managers may share an interest in presenting selfserving numbers to noncontrolling shareholders who buy minority stakes in the stock market. European lenders, meanwhile, tend to be large banks with insider access to information rather than dispersed bondholders who rely on published financials. Finally, should audit failure occur, with resulting injury to the blockholder, negative reputational consequences for the auditor will loom larger. The auditor, in effect, works for a small, closed society of top managers, large financial institutions and wealthy individuals. Within this corporate control club, information can be shared quickly and easily and reputational sanctions can be meted out more effectively than in a dispersed, market based system such as ours.

Given this different relational dynamic between auditor and client, a different rulebook easily could evolve. A blockholding system would more easily lend itself to accounting based on principles. But the fact that such a principles-based system worked well in a blockholder governance system gives us no reason to suppose that adoption of the blockholder system's approach would improve our system.

Sarbanes-Oxley section 108(a) follows from a cross reference hypothesis. This projects global convergence on corporate governance rules that eliminate systemic differences and from the emergence of a hybrid best practice. But the projection is not safe. Each national governance system is a system to a significant extent. Each system, rather than consisting of a loose collection of separable components, is tied together by a complex incentive structure. Interdependencies between each system's components and the incentives of its actors create significant barriers to cross reference to and from other systems. ${ }^{110}$

Sarbanes-Oxley's convergence projection assumes divisible accounting institutions-a world in which one accounting system's components can be adapted for use in the other system without significant frictions or perverse effects. But to the extent that differences in stockholding pat-

of minority shareholder rights and lax securities market regulation. This in turn chills the development of robust trading markets. Id. at 226-28 (footnotes omitted).

110. See id. at 258-71 (advocating for indivisible systems of corporate governance). 
terns lead to materially different relationships between auditors and clients, there is no reason to suppose that the systems' differing accounting principles can be merged into a hybrid regime for effective across-theboard application.

\section{ConClusion}

There can never be a one hundred percent directive rulebook in accounting any more than there is any other regulatory context. Nor can slavish rule application ever be trusted to yield perfect results. There is always a moment of judgment. Accordingly, GAAP of necessity always has and always will have mixed rules and principles. GAAP's present rules, applied in good faith, were more than adequate to pick up the material misstatements in Enron's financials. Contrary to the accounting firms' assertions, Enron's auditor did not proceed at the mercy of vague or incoherent instructions. Contrary to former Chairman Pitt's assertions, a move to standards solves nothing. Standards only work when the actor authorized to apply them takes responsibility for exercises of judgment. We accordingly need to keep our attention fixed on the fact that the recent governance breakdowns occurred entirely on the enforcement side. Auditors have stopped acting as neutral reviewers to take up client advocacy. Enron was an audit failure, and not a case where incomplete, ineffective or corrupt rules facilitated a fraud. Under this analysis, the drafters of Sarbanes-Oxley were right in thinking that the absence of principles has contributed to the crisis, but wrong in diagnosing the problem as legislative. This is not for the most part a problem concerning the relative merits of rules and standards in the drafting of statutes. It is instead a problem of professional practice in a regulatory system made up of both. It is the auditors who need to get back to principles, taking seriously principles already governing the reporting system. 
Villanova Law Review, Vol. 48, Iss. 4 [2003], Art. 2

1056

[Vol. 48: p. 1023 